\title{
Protein FAN
}

National Cancer Institute

\section{Source}

National Cancer Institute. Protein FAN. NCI Thesaurus. Code C104586.

Protein FAN (917 aa, $104 \mathrm{kDa}$ ) is encoded by the human NSMAF gene. This protein is involved in cell signaling via the TNF pathway. 